\title{
PARENTS' PERCEPTION ON IMPLEMENTING E-LEARNING DURING NEW NORMAL ERA AT RURAL SCHOOL
}

\author{
Balqis Husain ${ }^{1}$, Muhammad Iman Kofia ${ }^{2}$, Megawati Basri ${ }^{3}$, Nurhani Mahmud ${ }^{4}$ \\ ${ }^{1,2,3}$ Pendidikan Bahasa Inggris, Universitas Pasifik Morotai, \\ ${ }^{4}$ Pendidikan Guru Sekolah Dasar, Universitas Pasifik Morotai, \\ Coreesponding Email: balqishusain.bh@gmail.com,
}

Received: Nov 2, $2020 \quad$ Revised: Nov 5, $2020 \quad$ Accepted: Nov 10, 2020

\begin{abstract}
ABSTRAK
Tujuan dari penelitian ini untuk mengetahui persepsi orang tua terhadap penerapan pembelajaran berbasis elektronik pada masa kenormalan baru di sekolah yang terletak di daerah perbatasan. Jenis penelitian ini menggunakan penelitian kualitatif. Alat ukur penelitian menggunakan teknik wawancara dengan jenis wawancara "Open-ended question". Terdapat 13 item yang di ajukan kepada wali murid. Penelitian ini dilakukan pada orang tua/wali murid di SMP Cucumare. Jumlah responden sebesar 20 responden. Dalam menganalisis data, peneliti menggunakan analisis deskriptif. Hasil penelitian menunjukkan bahwa terdapat respon yang berbeda-beda dari orang tua/wali murid terhadap penerapan e-learning pada masa pandemic. Respon yang dikemukakan dikategorikan baik dalam bentuk positif maupun negative.
\end{abstract}

Kata kunci: Persepsi orang tua, e-learning, masa kenormalan baru, sekolah pedalaman

\begin{abstract}
Aim of this research was to know the parents' perception on implementing e-learning during new normal era at rural school. This research used qualitative research design. Instrument of this research utilized interviews through open-ended questions. There were 13 items asked the students' family members in particular parents. This research was conducted to the parents of the students who study at SMP Cucumare. The number of interviewees was 20 parents. To analyze the data the researcher used descriptive analyze. The result showed that there were heterogeneous responds was given by the parents toward the utilization of e-learning during pandemic era. It can be highlighted into positive and negative responds.
\end{abstract}

Keywords: Parents' perception, e-learning, new normal era, rural school

\section{INTRODUCTION}

Nowadays, the majority of people over the world deal with the new system life. Since the Covid-19 outbreaks bombards, all aspects of life have changed, without exception in the education field. All academic practitioners across the world are required to fully utilize elearning, either synchronous or asynchronous learning (Talebian et al., 2014). There is no 
doubt that the Indonesia government takes out obvious steps to tackle this phenomenon; it started by announcing the regulation of large-scale social restrictions until the newest regulation is implemented, such as new normal regulation. However, in the education aspect, Face to face learning classes are not allowed to reduce the activity of people. Education ministry requires all of the educational institutions to apply the virtual class. Electronic sites have become a prominent part of teaching-learning activity since transmission of Corona Virus-19 outbreaks. Over one decade, the adoption of electronic tools as a learning media increase rapidly due to this kind of learning promotes efficiency and as suit approaches in this digital era unless not all educational institutions have used this virtual learning (Sulisworo et al., 2016; Zhou et al., 2020). E-learning offers a variety of highly appropriate teaching tools that enable pupils to read through interactive classes and actively engage them in their studying and generate high-quality work (Ganie et al., 2014). This learning model has become more important as a teaching method, just as technology has advanced over the years. Oddly, more efforts have been made to improve technology than to seek on the learners' needs and learning style, and even the learning design (Samir Abou El-Seoud et al., 2014).

The utilization of electronic tools in the classroom facilitates the establishment of a learning model that generates a new paradigm of IT or well-known as E-Learning (Suryati et al., 2019). With the maturity of e-learning system development, so many more people see the Internet as a potential alternative study form (Cheng et al., 2007). E-learning is not about integrating ICT in classrooms so that it can start replacing educators with advanced technologies. E-learning is a process on which the students' learning process can be easily solved. Therefore, learners may be able to gain knowledge quickly, while many virtual materials can be displayed through e-learning (Abdallah, 2018; Saputra et al., 2017). Parents can also be allowed to invite the digital site to view their children (Daniels et al., 2019). The education institutions implement technology and information apps in the teaching-learning activity to integrate curricula with technology (Al-Mubireek, 2019).

Nevertheless, numerous educational institutions are optimistic because the entire technical problems produced by this sort of learning have been handled well. Conversely, for several schools, particularly in the remote areas, they deal with new dilemmas since learning activity must involve electronic equipment due to the pandemic's deployment. Students in many rural areas face natural and environmental disadvantages, making them less educational resources compare to urban students (Cheng et al., 2007). Besides, e-learning is integrated with Mechanism control; different parties are involved in this system, such as teachers, community members, and family members, in particular parents. However, the most 
important party is the parents themselves (Kusumawardani \& Ferdiana, 2013). Each parent is not prepared for the instruction role due to lack of experience, time as well as other restrictions (Smith et al., 2016). Smith and friends also add that parent-teacher's role may promote stereotype influence toward the dynamic of parent-child. It is considered to encourage both parents and children into frustration. By integrating parents into the learning process, parental roles can be significantly expanded, in particular online environments. Educational ICT path development is unique for every country from its own educational, social, cultural, as well as political aspects (Cheok et al., 2017).

North Maluku, particularly Morotai island regency, has implemented e-learning since the pandemic era. Various problems are voiced out when the academic practitioners begin to use the electronic device as a learning model. Those phenomena are categorized from technical problems, as well as parents' attitude to accept e-learning. Thus, based on survey has been done by researcher, technical problems consists of technology facilities and infrastructure. Whereas, factors of academic practitioners and parents' attitudes to accept elearning tend to lack parents' proficiency about ICT, lack awareness of parents' emotional control, and a number of the students' parents are categorized as having low levels of education. In addition, one of the biggest issues facing educators is that this model of learning should involve parental authority so that this learning model performs well in the pandemic period. In the covid-19 era, students are expected to learn independently while family members are becoming new essential partners and gain full command instead of educators (Zhou et al., 2020). Additionally, e-learning involves students working together and solving real issues through effective use of ICT (Cakrawati, 2017), the greatest question is how do parents handle this learning model, since these emotional, educational, and soft skills are not ready for all aspects? Parents are better aware of their children's needs and personal traits so that they become successful users of limited learning technology (Fedina et al., 2017). Learners, family members and educators should be made aware of its use internet, taking ethical rules into account (Kanthawongs \& Kanthawongs, 2013). Families are influential factors that can promote students' interest in schooling. Many cases are found in a rural school. In contrast, sadly, families do not see education as a key medium for life advancement and dampen the impact on student aspirations (Redding \& Walberg, 2012). However, a great number of voices have declared parental influences to promote the e-learning system have been conducted (Smith et al., 2016; Kusumawardani \& Ferdiana, 2013; Kanthawongs \& Kanthawongs, 2013; Fedina et al., 2017; Abdallah, 2018). The other prior studies highlight potential impact in various areas of life toward the implementation of e-learning on the first 
day of Covid-19, this study has been criticized by (Sahu, 2020; Darmalaksana et al., 2020; Verawardina et al., 2020; Zhou et al., 2020; Khan, 2020).

All in all, the parents' perspective about the implementation of any available elearning platform during Coronavirus deployment should be established. It is interesting to know what kind of limitations the parents face and how they survive to solve this phenomenon.

\section{METHOD}

This research used qualitative research design. Instrument of this research utilized interviews through open-ended questions. There were 13 items asked the students' family members in particular parents. This research was conducted to the parents of the students who study at SMP Cucumare. The number of interviewees was 20 parents. To analyze the data the researcher used descriptive analyze.

\section{RESULT AND DISCUSSION}

On this research, there were 13 items asked the students' family members in particular parents, based on the interview, there were various answers were given by interviewees. The number of items will be displayed by the table below;

Table 1. The Items of Interview

\begin{tabular}{cl}
\hline No & \multicolumn{1}{c}{ Items of Interview } \\
\hline 1 & Schools' policy on implementing e-learning in teaching-learning activities \\
2 & Parents' controlling to their children during the learning process take place \\
3 & The parents' proficiency in operating electronic devices \\
4 & The limitations are faced by the parents when guiding their children learning through \\
& ICT \\
5 & The solution to tackle those limitations \\
7 & The conveniences of e-learning during the pandemic \\
& The extent of e-learning application conducted by the schools before the existence of \\
8 & The parents' understanding of the materials given by the teachers that being taught to \\
& the children \\
10 & The parents' perception of traditional learning and e-learning \\
11 & A cooperative relationship between parents, students, and teachers \\
12 & The teachers' role on e-learning during the pandemic
\end{tabular}


When the researchers asked their first question, the interviewees had different responses. The first problem was to recognize the approach of schools in the area of elearning in teaching. Numerous parents had a positive mindset when education institutions declared that they would use e-learning during the phase of Covid-19, most of them felt that learning practices had to proceed in an era of pandemics and that e-learning was the best option. However, e-learning brought new ICT knowledge to students. They consider that schools should have additional e-learning costs and that the school and government should establish sufficient access to the Internet in order to make the e-learning process effective. They also claimed that the teachers should monitor the e-learning process as much as possible, as most of the students noticed that the Internet was used abusively for social media and not for learning purposes.

The second element was the monitoring of the parents towards their children during the learning process. Mostly during the e-learning cycle, more than half of the interviewees responded, they fully control their children. Control systems began from the brainstorming stage, while the materials were delivered, until the assignment stage. The parents' greatest desire was to know the child's success in every subject the teachers gave. Furthermore, parents have to control the children during the e-learning process, so that they still pay attention to the topics. The remains of the parents replied that the children were not under control due to much homework.

Based on the interviewees' responses to the third question, 62 percent of parents were familiar with electronic equipment and, in fact, with ICT. They thought it was easy to operate technology devices. Sadly, the rest are not acquainted with ICT, and they are listed as technologically backward.

Interviewees on the fourth item responded to varying responses. Over half of the parents claim they are low-income families. However, the high cost of the Internet is a significant problem, and e-learning often requires personal high-tech education. The other disadvantages of the e-learning model were the poor internet connection in rural area, as well as the tendency of students to use this learning model. Some of the parents assumed that their children were not prepared to change the learning style at the same time.

Based on the parents' reactions to the fifth item, it was analyzed that they offered a variety of solutions to overcome this phenomenon. They believed that there was a need for cooperation between local authorities and educational institutions to support this learning 
model, such as providing free internet access and preparing good internet connections. In addition, it is important for teachers to visit the students' homes regularly to ensure the condition, situation, and progress of the students.

The sixth item focused on the numerous conveniences e-learning was produced. $99 \%$ of the family members appointed that it brought benefits for the students. Most of them did not explain the benefits of e-learning, but several of them claim that it recently opened the students' understanding of the utilization of electronic devices as well as mastery of soft skills. $1 \%$ parent argued that there were no other advantages are provided by e-learning.

From the seventh item answered by the participants, 38 percent of respondents noticed that e-learning was adopted by schools a few years earlier. Ruang Guru Platform was one of the favorable software used by students. Ironically, the use of e-learning before the Covid-19 chain did not optimize. During the Corona Virus era, 62\% of parents thought that e-learning was introduced at $100 \%$.

The eighth item concerned the parents' understanding of the materials given by the teachers taught to the children. $19 \%$ of participants said they did not understand the materials taught by the teachers to their children. They prefer to hand over all of the learning activities to the teachers due to they consider the teachers' obligation. The rest of the parents argued that they understand the subjects and materials taught by the teachers because they were teachers.

Based on the respondents' arguments on the ninth item, it was identified that $99 \%$ of parents agree that conventional learning was effective compared to electronic learning. Some reasons were put forward by the parents; for instance; students' learning style was considered, whereas for the students to tend to kinesthetic learning style, they found it difficult to follow the virtual class. In addition, the face-to-face classroom promotes social life for students, on the other hand, reduces antisocial characteristics for children, encourages students to be creative, encourages students to be honest about their homework, and boosts students to study hard, and pushing students to learn quickly. Conversely, $1 \%$ of respondents believed that both electronic and conventional learning was effective.

$76 \%$ of parents claimed that the relationship between parents, students, and teachers was uncooperative. Parents have taken the initiative to control their children only if they want children to understand the material. Twenty-four percent of parents believed that it fostered a cooperative relationship though parents held full control while conducting the online home study. On the other hand, parents were an extension of the teacher so that teachers would actively guide parents about what they should do the e-learning process took place. 
Among Mathematics, Physic, as well as English subjects, were considered as difficult subjects to teach by virtual class. Most of the students found it difficult to catch those materials. $29 \%$ of interviewees argue that the English subject was the difficult one to understand, whereas $38 \%$ of interviewees believed that mathematics subject was the hard one. The rest of them claimed that physics subjects promoted a problematic situation for the students.

$100 \%$ of respondents declared that since the Covid-19 bombarded to the education aspect, the role of the teachers as educators have diminished due to almost all the teachers' role have been replaced by parents.

The last item was sorts of apps that are used on e-learning during the spreading of Covid-19. Most of them said that numerous apps were implemented in the e-learning class. The most favorable was the Whatsapp device. It was followed mix site; on the other hand, the teachers utilized more than one app for virtual classrooms, for instance, Ruang Guru, Messenger, and Google Classroom equipment.

Numerous previous studies highlight the utilization of e-learning during the pandemic. E-learning as a challenge for digital leaders of the $21^{\text {st }}$ century, this is effective to implement on the work from home (WFH) period due to Covid-19 outbreaks (Darmalaksana et al., 2020). E-learning or distance learning seems to be essential for an educational instrument; moreover, there are several obstacles to incorporate the educational concepts effectively to achieve pre-determined goals and achievements. Distance learning was concluded as the only way to continue education when the COVID-19 interrupted the international education scene. Nevertheless, adequate human resource management and operational readiness are necessary (Khan, 2020). The similar study conducted by Basri et al., (2020) found that the limited ability of the internet access was one of the most crucial issues that needed to be solved when introducing asynchronous learning (Screencast-O-Matic and Google-Form apps). ScreencastO-Matic and Google-Form have drawbacks in their virtual class; however, they do have more advantages. Many respondents felt that it is stronger compared to its drawbacks. In a majority of respondents, the internet and information technology (IT) helped EFL students to acquire linguistic knowledge related to writing skills.

The effect on school-disrupted learning can be reduced by introducing online learning. This article addresses online preparation for the outbreak of Covid-19. The study results showed that preparation is a necessary, clear step in applying online learning, the teacher's role, the students' role, the strengths of online courses, and resolving online learning constraints (Verawardina et al., 2020). Appropriate advice should be provided to support the 
Students' mental health and well-being. Authorities must take responsibility for ensuring that international students obtain food and accommodation. Members of the faculty should include technology and students' experience carefully to make learning productive and successful. Sahu, (2020) Using "School Out, But Class On," it has been a beneficial opportunity to improve the integration of innovative technology and education and modernize the instructional system of teaching in a new setting. Nonetheless, online education also represents other issues in the implementation process. For instance, in online education, some teachers copy teaching material for online teaching, ignoring subjective instruction and lack of contact between the teacher and the student as well as lousy teaching performance. Simultaneously, some students lacked a face-to-face teacher or parental guidance due to a lack of self-control and self-learning capacity. The overall impact of independent learning has not been workable (Zhou et al., 2020). In addition, Husain et al., (2020) claims that the majority of the teachers used various platforms to prepare themselves during the lockdown. Single teaching or mixed teaching can lead to the maximum and best results in instructional activities. Nine advantages of e-learning were discussed, but there were seven downside of e-learning too. Educators were proposing new ideas to make many of the students competitive.

Another prior research has been done by Smith et al., (2016), this study highlights how to best help school officials and online learning providers for parents and students with disorders; Improving guidance for both parents and students with special needs: clarifying the roles of parents and teachers; understanding the crucial elements of accomplishments in a wholly digital context; responding to the demands of parents and their children with special needs, as well as any need for regular home-school interaction; And mandate training programs to ensure that parents have the qualifications they need to take an active part in their child's schooling through this online platform. Besides, Fedina et al., (2017) try to compare the outcomes of urban and rural areas using e-learning. The percentage of who expressed the intention of using such e-learning implementing methods is much higher than in the city. It was also demonstrated that a relatively limited proportion of the parents interviewed work with the PEI website. This may mean that to date, parents have not used the websites as a basis of educational information. Specialized online classes with a professor/specialist are the most common way for remote learning in both the city and the country. Abdallah (2018), also declares a study about the perception of United Arab Emirates parents implementing elearning. The analysis indicates major gaps in the parents' view of e-learning in Abu Dhabi 
across public and private schools. Therefore, private schools need to concentrate more on elearning, and ADEK needs to adopt and monitor it. Refers to the perception of parents, parents are not satisfied with e-learning while at the same time, most target respondents do not know e-learning. Culture affects the understanding of parents; in fact, e-learning may inhibit society's culture.

\section{CONCLUSION}

Variant responds were given by the parents toward the utilization of e-learning during pandemic era. It included both positive and negative responds. Positive responds can be listed: e-learning brought new ICT knowledge to students; parents fully control systems of elearning, it began from the brainstorming stage, while the materials were delivered, until the assignment stage; the parents were familiar with electronic equipment; during the Corona Virus era, e-learning was introduced at $100 \%$; the majority of parents have a job as teachers, so it was easy for them to teach their children; numerous apps were implemented in the elearning class. The most favorable was the Whatsapp device. It was followed mix site; on the other hand, the teachers utilized more than one app for virtual classrooms, for instance, Ruang Guru, Messenger, and Google Classroom equipment.

However, e-learning brought some disadvantages for the parents, such as; the role of the teachers as educators have diminished due to almost all the teachers' role have been replaced by parents; $99 \%$ of parents agree that conventional learning was effective compared to electronic learning; $76 \%$ of parents claimed that the relationship between parents, students, and teachers was uncooperative; Among Mathematics, Physic, as well as English subjects, were considered as difficult subjects to teach by virtual class; over half of the parents claim they were low-income families. However, the high cost of the Internet is a significant problem, and e-learning often requires personal high-tech education. The other disadvantages of the e-learning model were the poor internet connection in rural area, as well as the tendency of students to use this learning model. Some of the parents assumed that their children were not prepared to change the learning style at the same time.

Besides, the parents offered a variety of solutions to overcome this phenomenon. They believed that there was a need for cooperation between local authorities and educational institutions to support this learning model, such as providing free internet access and preparing good internet connections. In addition, it is important for teachers to visit the students' homes regularly to ensure the condition, situation, and progress of the students.

In addition, this study is as basic information for the other researchers who interest to conduct the similar research with different variables. Besides, this study can be benchmark for 
the local government in particular educational principal to take out policy by considering those obstacles of e-learning.

\section{REFERENCES}

Abdallah, A. K. (2018). Parents Perception of E-Learning in Abu Dhabi Schools in United Arab Emirates. IJASOS- International E-Journal of Advances in Social Sciences, 4(September), 30-41. https://doi.org/10.18769/ijasos.415513

Al-Mubireek, S. (2019). E-learning in the English Classroom: Comparing Two E-Learning Platforms Impacting Preparatory Year Students' Language Learning. Call-Ej, 20(2), 1937. http://callej.org/journal/20-2/Al-Mubireek2019.pdf

Basri, M., Husain, B., \& Modayama, W. (2020). University Students 'Perceptions in Implementing Asynchronous Learning During Covid-19 Era. METATHESIS Journal of English Language, Literature, and Teaching, 4(3), 263-276. https://doi.org/10.31002/metathesis.v4i3.2734

Cakrawati, L. M. (2017). Students' Perceptions on the Use of Online Learning Platforms in EFL Classroom. English Language Teaching and Technology Journal 9ELT-Tech Journal), 1(1), 22-30. http://ejournal.upi.edu/index.php/ELTTech/article/view/9428

Cheng, S., Liu, E., Ko, H., \& Lin, C. (2007). Learning with Online Tutoring: Rural Area Students' Perception of Satisfaction with Synchronous Learning. International Journal of ..., April, 36-42.

http://www.gec.ntut.edu.tw/ezfiles/17/1017/attach/46/pta_1292_4088514_07607.pdf

Cheok, M. L., Wong, S. L., Ayub, A. F., \& Mahmud, R. (2017). Teachers' perceptions of ELearning in Malaysian Secondary Schools. Malaysian Online Journal of Educational Technology, 5(2), 20-33. https://files.eric.ed.gov/fulltext/EJ1142390.pdf

Daniels, M. M., Sarte, E., \& Cruz, J. Dela. (2019). Students' Perception on E-Learning: A Basis for the Development of E-Learning Framework in Higher Education Institutions. IOP Conference Series: Materials Science and Engineering, 482(1), 1-7. https://doi.org/10.1088/1757-899X/482/1/012008

Darmalaksana, W., Hambali, R. Y. A., Masrur, A., \& Muhlas. (2020). Analisis Pembelajaran Online Masa WFH Pandemic Covid-19 sebagai Tantangan Pemimpin Digital Abad 21. Karya Tulis Ilmiah (KTI) Masa Work From Home (WFH) Covid-19 UIN Sunan Gunung Djati Bandung Tahun 2020, 1(1), 1-12. http://digilib.uinsgd.ac.id/30434/

Fedina, N. V., Burmykina, I. V., Zvezda, L. M., Pikalova, O. S., Skudnev, D. M., \& Voronin, I. V. (2017). Study of Educators' and Parents' Readiness to Implement Distance Learning Technologies in Preschool Education in Russia. Eurasia Journal of Mathematics, Science and Technology Education, 13(12), 8415-8428. https://doi.org/10.12973/ejmste/80802

Ganie, M. A., Molvi, S. A., \& Ali, M. (2014). Impact of E-learning on Child Education and Development in Rural Areas of India. International Conference on E-Business, $e$ Commerce, e-Management, e-Learning and e-Governance, 2020(March 2020), 77-82. https://doi.org/10.978.819252/12223

Husain, B., Idi, Y. N., \& Basri, M. (2020). Teachers' Perceptions on Adopting e-Learning during COVID-19 Outbreaks; Advantages, Disadvantages, Suggestions. Jurnal Tarbiyah, 27(2), 41-57. https://doi.org/http://dx.doi.org/10.30829/tar.v27i2.738

Kanthawongs, P., \& Kanthawongs, P. (2013). Perception of Primary School Students, Parents and Teachers toward the Use of Computers, the Internet and Social Networking sites. Procedia - Social and Behavioral Sciences, 88, 282-290. https://doi.org/10.1016/j.sbspro.2013.08.507 
Khan, I. A. (2020). Electronic Learning Management System : Relevance, Challenges and Preparedness. Journal of Emerging Technologies and Innovative Research ((JETIR), 7(5), 471-480.

https://d1wqtxts1xzle7.cloudfront.net/63286717/JETIR200507220200512-324001ynnf6.pdf?1589300548=\&response-content-

disposition=inline\%3B+filename\%3DElectronic_Learning_Management_System_Re.pd f\&Expires $=1594297267 \&$ Signature $=$ cfutSdRoGOHnrWs3p1R-LwnHqsXoisi7D7

Kusumawardani, S. S., \& Ferdiana, R. (2013). Parental Control Model for High School ELearning. Forum Teknik, 35(1), 42-49. file:///C:/Users/hp/Downloads/4446-7437-1-SM (1).pdf

Redding, S., \& Walberg, H. J. (2012). Promoting Learning in Rural Schools. In P. S. Lori Thomas (Ed.), Academic Development Institute. Academic Development Institute. http://libproxy.library.wmich.edu/login?url=https://search.proquest.com/docview/191334 8961 ?accountid=15099\%0Ahttps://primo-

pmtna01.hosted.exlibrisgroup.com/openurl/01WMU/01WMU?url_ver=Z39.882004\&rft_val_fmt=info:ofi/fmt:kev:mtx:book\&genre=report\&sid=ProQ

Sahu, P. (2020). Closure of Universities Due to Coronavirus Disease 2019 (COVID-19): Impact on Education and Mental Health of Students and Academic Staff. Cureus, 2019(4), 4-9. https://doi.org/10.7759/cureus.7541

Samir Abou El-Seoud, M., Taj-Eddin, I. A. T. F., Seddiek, N., El-Khouly, M. M., \& Nosseir, A. (2014). E-Learning and Students' Motivation: A Research Study on the Effect of ELearning on Higher Education. International Journal of Emerging Technologies in Learning, 9(4), 20-26. https://doi.org/10.3991/ijet.v9i4.3465

Saputra, A. S., Kusumawardani, S. S., \& Nugroho, E. (2017). Pengembangan Model Awal Sistem Evaluasi Penerimaan Pengguna E-Learning Janabadra. Prociding SENIATI 2017 (BOOK-1), 1(B3), 1-6. https://ejournal.itn.ac.id/index.php/seniati/article/view/1616

Smith, S., Burdette, P., Cheatham, G., \& Harvey, S. (2016). Parental Role and Support for Online Learning of Students with Disabilities: A Paradigm Shift. Journal of Special Education Leadership, 29(2), 101-112. https://files.eric.ed.gov/fulltext/EJ1118423.pdf

Sulisworo, D., Ishafit, \& Firdausy, K. (2016). The Development of Mobile Learning Application Using Jigsaw Technique. International Journal of Interactive Mobile Technologies, 10(3), 11-16. https://doi.org/10.3991/ijim.v10i3.5268

Suryati, T., Suryana, \& Kusnendi. (2019). The Effect of E-Learning Based on Schoology and Student Interest to Metacognitive Thinking Skill of Vocational High School Students in Archival Subject. International Journal of Research and Review, 6(December), 397-404. https://doi.org/inrein.com/10.4444/ijrr.1002/1594

Talebian, S., Mohammadi, H. M., \& Rezvanfar, A. (2014). Information and Communication Technology (ICT) in Higher Education: Advantages, Disadvantages, Conveniences and Limitations of Applying E-learning to Agricultural Students in Iran. Procedia - Social and Behavioral Sciences, 152, 300-305. https://doi.org/10.1016/j.sbspro.2014.09.199

Verawardina, U., Asnur, L., Lubis, A. L., Hendriyani, Y., Ramadhani, D., Dewi, I. P., Darni, R., Betri, T. J., Susanti, W., \& Sriwahyuni, T. (2020). Reviewing online learning facing the Covid-19 outbreak. Talent Development and Excellence, 12(SpecialIssue3), 385392. http://www.iratde.com/index.php/jtde/article/view/281

Zhou, L., Wu, S., Zhou, M., \& Li, F. (2020). 'School's Out, But Class' On', The Largest Online Education in the World Today: Taking China's Practical Exploration During The COVID-19 Epidemic Prevention and Control As an Example. SSRN Electronic Journal, 4(2), 501-519. https://doi.org/10.2139/ssrn.3555520 